\title{
Pengembangan instrumen penilaian psikomotor berbasis proyek untuk meningkatkan kompetensi psikomotor siswa dalam pembelajaran Blended Learning di era new normal
}

\author{
Giarti Ningsih, Wening Patmi Rahayu* \\ Universitas Negeri Malang, Jl. Semarang No. 5 Malang, Jawa Timur, Indonesia \\ *Penulis korespondensi, Surel: wening.patmi.fe@um.ac.id
}

Paper received: 3-5-2021; revised: 24-5-2021; accepted: 28-5-2021

\begin{abstract}
Abstrak
Perkembangan kurikulum di Indonesia menyebabkan adanya perubahan dalam menentukan standar penilaian pendidikan. Kurikulum 2013 revisi merupakan kurikulum yang saat ini berlaku di Indonesia. Dengan diterapkannya kurikulum 2013 revisi maka menyebabkan standar penilaian mengalami perubahan, yang mana sebelumnya lebih berfokus pada hasil sedangkan pada kurikulum 2013 kegiatan penilaian lebih berfokus pada proses pembelajaran peserta didik. Namun, adanya covid-19 yang saat ini terjadi di Indonesia menyebabkan kegiatan pembelajaran dilakukan secara online. Namun setelah diterapkannya new normal kegiatan pembelajaran dilakukan dengan mengkombinasikan antara kegiatan pembelajaran online dan tatap muka atau disebut blended learning. Adanya perubahan dalam kegiatan pembelajaran maka kegiatan penilaian yang dilakukan oleh guru juga sedikit mengalami perubahan. Dengan pembelajaran secara online maka kegiatan penilaian aspek psikomotor cukup sulit untuk dilakukan, sehingga tidak sedikit guru yang melakukan kegiatan penilaian lebih berfokus pada aspek kognitif. Untuk mengatasi hal tersebut instrumen penilaian psikomotor berbasis proyek yang dikembangkan secara khusus untuk kegiatan pembelajaran dengan blended learning menjadi salah satu alternatif yang dapat digunakan oleh dalam melakukan penilaian aspek psikomotor. Penilaian proyek merupakan kegiatan penilaian terhadap suatu tugas proyek yang harus diselesaikan dalam kurun waktu tertentu.
\end{abstract}

Kata kunci: Penelitian dan Pengembangan; Penilaian Psikomotor; Penilaian Proyek; Blended Learning

\section{Pendahuluan}

Kurikulum di Indonesia sudah mengalami beberapa kali perubahan hingga saat ini. Kurikulum 2013 revisi merupakan kurikulum yang saat ini berlaku di Indonesia. Berdasarkan UU Nomor 20 Tahun 2003 tentang Sistem Pendidikan Nasional kurikulum merupakan seperangkat rencana dan pengaturan yang digunakan sebagai pedoman penyelenggaraan kegiatan pembelajaran yang berisi mengenai tujuan, isi, bahan pelajaran, dan cara yang digunakan untuk mencapai tujuan pendidikan nasional. Berdasarkan Permendikbud No. 34 Tahun 2018 tentang Standar Nasional Pendidikan Menengah Kejuruan / Madrasah Aliyah Kejuruan, standar penilaian pendidikan merupakan salah satu unsur yang mengalami perubahan karena adanya penerapan kurikulum 2013 revisi. Standar penilaian pendidikan yang meliput penilaian kognitif, psikomotor dan afektif digunakan sebagai dasar untuk mengetahui dan mengukur hasil belajar peserta didik.

Berdasarkan Permendikbud No. 34 Tahun 2018 tentang Standar Nasional Pendidikan Menengah Kejuruan / Madrasah Aliyah Kejuruan, standar penilaian pendidikan adalah kriteria minimal yang digunakan sebagai dasar dalam melakukan penilaian hasil belajar peserta didik yang mencakup lingkup, tujuan, manfaat, prinsip, mekanisme, prosedur, dan instrumen penilaian hasil belajar peserta didik. Penilaian merupakan proses pengumpulan informasi 
yang secara menyeluruh dan berkesinambungan terkait proses serta hasil belajar yang telah dicapai oleh peserta didik selama proses pembelajaran (Pramana \& Putra, 2019). Salah satu bentuk penilaian psikomotor yang dapat digunakan yaitu penilaian berbasis proyek.

Penilaian proyek menurut Kunandar (2013:286) merupakan kegiatan penilaian terhadap suatu tugas yang meliputi pengumpulan, pengorganisasian, pengevaluasian, dan penyajian data yang harus diselesaikan peserta didik baik secara individu/kelompok dalam waktu atau periode tertentu. Berdasarkan penelitian yang dilakukan oleh Saputra, Eka Heru, dkk (2018) dengan judul Developing Performance-based Authentic Assessment Instruments in Learning Productive Marketing of Merchandise Planning Subject (A Study in the XIth Marketing Class in SMKN 1 Turen Kabupaten Malang), menunjukkan hasil bahwa tanggapan guru terhadap kepraktisan instrumen penilaian dengan kriteria "mudah digunakan" dan keterbacaan lembar kerja siswa dengan kriteria "mudah digunakan". Instrumen penilaian yang digunakan harus menekankan aspek psikomotor. Berdasarkan hal tersebut, sehingga dalam melakukan penilaian diperlukan instrumen penilaian khusus agar penilaian dapat dilakukan secara objektif dan valid.

Awal mula menerapkan pembelajaran daring yaitu disebabkan adanya virus Covid-19 yang mana pada awal bulan Maret 2020 sudah mulai menyebar di Indonesia. Kemudian, dengan diterapkan New Normal di Indonesia, pada bulan Oktober 2020 proses pembelajaran dilakukan dengan menerapkan Blended Learning. Wijoyo, dkk (2020:2) blended learning merupakan sebuah kombinasi pengajaran langsung (face to face) dengan pengajaran online, tetapi selain itu sebagai elemen dari interaksi sosial. Berdasarkan penelitian yang dilakukan oleh Wardani, dkk (2018) dengan judul Daya tarik Pembelajaran di Era 21 dengan Blended Learning. Hasil dari penelitian yang dilakukan menunjukkan bahwa pembelajaran blended learning interaksi dan komunikasi antar peserta didik dan antara guru dan peserta didik dapat terus berlangsung dan hal tersebut merupakan daya tarik pada pembelajaran di era 21 .

Penelitian sebelumnya yang membahas tentang pengembangan instrumen penilaian psikomotor berbasis proyek telah banyak dilakukan akan tetapi tidak berfokus pada pembelajaran blended learning antara lain sebagai berikut Lestari, Dwi, dkk (2015); Pasaribu, Abidin \& Saparini (2016); Sukmasari, Vidya Putri \& Rosana, Dadan (2017); Pamungkasi, Wilis Okti, dkk. (2017) dan Rahayu, Wening Patmi, dkk. (2020).

\section{Hasil dan Pembahasan}

Bagian ini memaparkan pengertian dari penilaian, penilaian proyek, ranah psikomotor dan blended learning. Berikut merupakan masing-masing penjelasannya:

\subsection{Penilaian}

Menurut Kusaeri (2014:17) penilaian merupakan suatu prosedur sistematis yang mencakup kegiatan mengumpulkan, menganalisis, dan menginterpretasikan informasi yang digunakan sebagai bahan untuk membuat sebuah kesimpulan tentang karakteristik seseorang atau objek. Penilaian yang dilakukan harus mempunyai prosedur yang sistematis dan berkesinambungan agar menghasilkan sebuah keputusan yang valid dan bermakna. Pengambilan keputusan dalam melakukan penilaian digunakan oleh seorang guru untuk menentukan sebuah tindakan selanjutnya yang harus dilakukan oleh peserta didik. 
Menurut Kusaeri (2014:17) tujuan penilaian perlu diarahkan pada empat hal, sebagai berikut: (1) Penelusuran (keeping track, (2) Pengecekan (checking-up), (3) Pencarian (findingout), (4) Penyimpulan (summing-up).

Menurut Majid (2014:29-30) menyatakan bahwa terdapat beberapa tahapan yang harus dilakukan dalam melakukan penilaian hasil belajar, sebagai berikut: (1) menentukan tujuan; (2) menentukan rencana penilaian; (3) penyusunan instrumen penilaian; (4) pengumpulan data atau informasi; (5) analisa dan interpretasi; (6) tindak lanjut

Menurut Kunandar (2013:291) kriteria yang harus dipenuhi dalam menyusun rubrik penilaian,adalah sebagai berikut: (1) Rubrik penilaian mempunyai validitas; (2) Rubrik penilaian sesuai dengan tujuan pembelajaran; (3) Indikator yang dibuat menunjukkan kemampuan peserta didik yang dapat diamati dan diukur; (4) Rubrik penilaian yang dihasilkan dapat memetakan kemampuan peserta didik; (5) Rubrik penilaian mampu menilai aspek penting yang terdapat pada tugas proyek

\subsection{Penilaian Proyek}

Menurut Kusaeri (2014:156) penilaian proyek merupakan kegiatan penilaian terhadap suatu tugas yang harus diselesaikan seorang atau sekelompok siswa dalam periode atau waktu tertentu. Kerja proyek merupakan bentuk pembelajaran kontekstual yang menekankan pada pemecahan masalah melalui suatu usaha kolaboratif (Wijayanti, 2014:103). Penilaian berbasis proyek dapat digunakan untuk menganalisis tingkat pemahaman dan kemampuan peserta didik dalam mengimplementasikan ilmu yang sudah diperoleh. Penilaian proyek dilaksanakan terhadap persiapan, pelaksanaan, dan hasil. Penilaian proyek merupakan salah cara untuk mencapai tujuan pembelajaran dengan mengakomodasi berbagai perbedaan gaya belajar, bakat, dan minat dari setiap peserta didik.

Menurut Ansori (2017:7) dalam melakukan penilaian proyek terdapat empat hal yang perlu dipertimbangkan, sebagai berikut: (1) pengelolaan, (2) relevansi, (3) keaslian, (4) inovasi dan kreativitas.

Menurut Majid (2014:108) terdapat dua jenis rubrik penilaian yang dapat digunakan dalam melakukan penilaian proyek, yaitu sebagai berikut: (1) Rubrik Holistik, yaitu penskoran dilakukan secara keseluruhan atau kesatuan produk tanpa melakukan penilaian setiap komponen secara terpisah; (2) Rubrik Analitik, yaitu penskoran dilakukan pada setiap bagianbagian individual produk atau secara terpisah kemudian skor pada setiap bagian dijumlahkan untuk memperoleh skor total; (3) Jenis rubrik penilaian yang dapat digunakan pada penilaian proyek salah satunya adalah rubrik holistik yang dapat dilihat pada tabel 1 , sebagai berikut:

Tabel 1. Contoh Rubrik Penilaian Tugas Proyek Bentuk Holistik

\begin{tabular}{llll}
\hline \multirow{2}{*}{ Aspek } & \multicolumn{3}{c}{ Kriteria Skor } \\
\cline { 2 - 4 } & \multicolumn{1}{c}{$\mathbf{3}$} & \multicolumn{1}{c}{$\mathbf{2}$} & \multicolumn{1}{c}{$\mathbf{1}$} \\
\hline Persiapan & Memuat tujuan, topik, & Memuat tujuan, topik, & Memuat tujuan, topik, \\
& alasan, tempat & alasan, tempat & alasan, tempat \\
& penelitian, daftar & penelitian, daftar & penelitian, daftar \\
& pertanyaan dengan & pertanyaan kurang & pertanyaan tidak \\
& lengkap & lengkap & lengkap \\
Pengumpulan & Daftar pertanyaan & Daftar pertanyaan & Pertanyaan tidak \\
Data & dapat dilaksanakan & dapat dilaksanakan & terlaksana semua dan
\end{tabular}




\begin{tabular}{|c|c|c|c|}
\hline \multirow{2}{*}{ Aspek } & \multicolumn{3}{|c|}{ Kriteria Skor } \\
\hline & 3 & 2 & 1 \\
\hline & $\begin{array}{l}\text { semua dan data } \\
\text { tercatat dengan rapi } \\
\text { dan lengkap }\end{array}$ & $\begin{array}{l}\text { semua tetapi data } \\
\text { tidak tercatat dengan } \\
\text { rapi dan lengkap }\end{array}$ & $\begin{array}{l}\text { data tidak tercatat } \\
\text { dengan rapi }\end{array}$ \\
\hline $\begin{array}{l}\text { Pengolahan } \\
\text { Data }\end{array}$ & $\begin{array}{l}\text { Pembahasan data } \\
\text { sesuai tujuan } \\
\text { penelitian }\end{array}$ & $\begin{array}{l}\text { Pembahasan data } \\
\text { kurang } \\
\text { menggambarkan } \\
\text { tujuan penelitian }\end{array}$ & $\begin{array}{l}\text { Sekadar melaporkan } \\
\text { hasil penelitian tanpa } \\
\text { membahas data }\end{array}$ \\
\hline $\begin{array}{l}\text { Pelaporan } \\
\text { Tertulis }\end{array}$ & $\begin{array}{l}\text { Sistematika penulisan } \\
\text { benar, memuat saran } \\
\text { dan menggunakan } \\
\text { bahasa yang } \\
\text { komunikatif }\end{array}$ & $\begin{array}{l}\text { Sistematika penulisan } \\
\text { benar, memuat saran } \\
\text { namun bahasa kurang } \\
\text { komunikatif }\end{array}$ & $\begin{array}{l}\text { Penulisan kurang } \\
\text { sistematis, kurang } \\
\text { memuat saran dan } \\
\text { bahasa kurang } \\
\text { komunikatif }\end{array}$ \\
\hline
\end{tabular}

(Sumber: Ansori, 2017:8-9)

Jenis rubrik penilaian yang dapat digunakan pada penilaian proyek salah satunya adalah rubrik analitik yang dapat dilihat pada tabel 2 , sebagai berikut:

Tabel 2. Contoh Rubrik Penilaian Tugas Proyek Bentuk Analitik

\begin{tabular}{lll}
\hline No & \multicolumn{1}{c}{ Aspek } & Skor \\
\hline 1 & Perencanaan: & 6 \\
& Latar Belakang (tepat = 3, kurang tepat = 2, tidak tepat = 1) \\
& Rumusan Masalah (tepat = 3, kurang tepat = 2, tidak tepat = 1) \\
& Pelaksanaan: \\
& Pengumpulan data/informasi (akurat = 3, kurang akurat = 2, tidak akurat = 1) \\
& Kelengkapan data (lengkap = 3, kurang lengkap = 2, tidak lengkap = 1) \\
& Pengolahan dan analisis data (sesuai = 3, kurang sesuai = 2, tidak sesuai =1) \\
& Simpulan (tepat = 3, kurang tepat = 2, tidak tepat = 1) \\
& Pelaporan hasil: \\
& Sistematika Laporan (baik = 3, kurang baik = 2, tidak baik = 1) \\
& Penggunaan Bahasa (sesuai kaidah = 3, kurang sesuai kaidah = 2, tidak sesuai \\
& kaidah = 1) \\
& Tampilan (menarik = 3, kurang menarik = 2, tidak menarik = 1) \\
Skor & Maksimal
\end{tabular}

Menurut Haryati (2007) beberapa kelebihan dari penilaian proyek adalah sebagai berikut: (1) Project work merupakan bagian internal dari proses pembelajaran terstandar, bermuatan pedagogis dan bermakna bagi peserta didik; (2) Memberikan kesempatan kepada peserta didik untuk mengekspresikan kompetensi yang dikuasainya secara utuh; (3) Lebih efisien dan menghasilkan sebuah produk; (4) Menghasilkan penguasaan kompetensi yang dapat dipertanggungjawabkan.

Menurut Murphy (dalam Ansori, 2017:4-5) kekurangan pada penilaian proyek adalah sebagai berikut: (1) Membutuhkan banyak waktu bagi guru dalam proses penilaian; (2) Membutuhkan banyak waktu dalam melakukan pengawasan untuk menjamin keterlaksanaan tugas yang dikerjakan peserta didik; (3) Tingkat kesulitan peserta didik dalam menyelesaikan proyek tidak sama, karena tingkat kemampuan dan pemahaman setiap peserta didik tidak sama; (4) Peserta didik tidak mempunyai kesempatan untuk mengulang tugas proyek yang sama jika mengalami kegagalan karena waktu yang dibutuhkan cukup panjang. 
Menurut Sani (2016:267-268) terdapat beberapa langkah yang harus dipenuhi oleh guru dalam melakukan perencanaan instrumen penilaian proyek, sebagai berikut: (1) Menentukan kompetensi yang sesuai untuk dinilai melalui pembuatan proyek; (2) Menyusun indikator proses dan hasil belajar berdasarkan kompetensi; (3) Menentukan kriteria yang menunjukkan capaian indikator pada setiap tahapan pengerjaan proyek; (4) Merencanakan apakah tugas dikerjakan secara individual atau kelompok; (5) Merencanakan teknik-teknik dalam penilaian individu untuk tugas yang dikerjakan secara kelompok; (6) Menyusun rubrik penilaian sesuai dengan tahapan pengerjaan proyek

\subsection{Ranah Psikomotor}

Berdasarkan Permendikbud No. 23 Tahun 2016 tentang Standar Penilaian Pendidikan pada pasal 3 penilaian hasil belajar peserta didik pada pendidikan dasar dan pendidikan menengah meliputi aspek sikap, pengetahuan, dan keterampilan. Menurut Mayasari (2020:79) ranah psikomotor merupakan ranah yang berhubungan dengan aktivitas fisik misalnya melompat, berlari, dan sebagainya. Menurut Dave (1967) dalam Majid (2014:52-53) mengatakan bahwa hasil belajar psikomotor dapat dibedakan menjadi lima tahap, yaitu sebagai berikut: (1) imitasi, (2) manipulasi, (3) presisi, (4) artikulasi, (5) naturalisasi.

Menurut Ryan (dalam Suryadi, 2020:54-55) menjelaskan bahwa hasil belajar psikomotor dapat diukur melalui beberapa hal, sebagai berikut: (1) Pengamatan secara langsung dan penilaian perilaku peserta didik selama proses pembelajaran praktik berlangsung; (2) Setelah mengikuti pembelajaran, yaitu dengan cara memberikan tes (uji coba) kepada peserta didik untuk mengukur penilaian dalam aspek kognitif, psikomotor, dan afektif; (3) Memberikan penilaian kepada peserta didik setelah pembelajaran selesai.

\subsection{Blended Learning}

Menurut Usman (2018:138) blended learning adalah suatu pembelajaran yang menggabungkan penerapan pembelajaran tradisional di dalam kelas dengan pembelajaran online yang memanfaatkan teknologi informasi. Metode blended learning merupakan salah satu tuntutan yang harus dilakukan dalam dunia pendidikan sebagai bentuk dari perkembangan teknologi yang semakin cepat.

Menurut Watson (2008) tujuan dari pembelajaran blended learning, adalah sebagai berikut: (1) Membantu peserta didik untuk berkembang lebih baik dari segi proses belajar, sesuai dengan gaya belajar dari setiap peserta didik, (2) Menyediakan peluang yang praktis dan realistis bagi guru dan peserta didik untuk pembelajaran secara mandiri, bermanfaat, dan terus berkembang, (3) Meningkatkan fleksibilitas bagi peserta didik, dengan menggabungkan kelebihan dari pembelajaran tatap muka dan pembelajaran online.

Menurut Carman (2005) dalam Widiara (2018:51-52) mengungkapkan bahwa terdapat lima kunci untuk melaksanakan pembelajaran dengan menggunakan blended learning, antara lain sebagai berikut: (1) live event, (2) self-paced learning, (3) collaboration, (4) assessment, (5) performance support material.

Menurut Widiara (2018:55) penerapan pembelajaran blended learning mempunyai kelebihan dan kekurangan, antara lain sebagai berikut: 
Kelebihan pembelajaran blended learning: (1) Proses pembelajaran dapat dilakukan kapan saja dan dimana saja dengan memanfaatkan sistem jaringan internet. (2) Peserta didik mempunyai keleluasaan untuk mempelajari materi atau bahan ajar secara mandiri dengan memanfaatkan beberapa website di internet untuk menambah wawasan peserta didik. (3) Kegiatan diskusi dapat berlangsung secara online dan tatap muka. Kegiatan diskusi dapat berlangsung secara baik antara guru dan peserta didik atau antar peserta didik itu sendiri. (4) Guru dapat mengelola dan mengontrol pembelajaran yang dilakukan peserta didik di luar jam pelajaran. (5) Guru dapat meminta peserta didik untuk mengkaji materi pelajaran yang akan dibahas sebelum pembelajaran tatap muka berlangsung dengan menyiapkan tugas-tugas pendukung. (6) Pencapaian target materi dapat disesuaikan dengan target yang ditetapkan. (7) Pembelajaran bersifat fleksibel dan tidak kaku.

Kekurangan pembelajaran blended learning: (1) Guru harus memiliki keterampilan dalam melaksanakan pembelajaran secara online (e-learning). (2) Guru memerlukan waktu untuk mengembangkan dan mengelola pembelajaran dengan sistem e-learning. (3) Guru harus menyiapkan referensi digital (secara online) sebagai bahan peserta didik untuk belajar dan referensi digital yang diberikan harus terintegrasi dengan pembelajaran tatap muka. (4) Sarana dan prasarana pendukung yang tidak merata serta rendahnya pemahaman tentang teknologi. (5) Guru harus menyiapkan strategi pembelajaran yang efektif untuk memaksimalkan potensi blended learning.

\section{Simpulan}

Perkembangan kurikulum di Indonesia menjadi salah satu faktor yang menyebabkan adanya perubahan dalam pembuatan sebuah instrumen penilaian. Instrumen penilaian adalah suatu alat ukur yang digunakan oleh guru untuk mengetahui perkembangan peserta didik dalam mencapai kompetensi. Instrumen penilaian psikomotor berbasis proyek merupakan salah satu instrumen penilaian yang digunakan oleh guru untuk mengetahui perkembangan peserta didik dalam mencapai aspek psikomotor dengan memberikan lembar kerja proyek. Namun, adanya covid-19 menyebabkan kegiatan penilaian psikomotor tidak dapat dilakukan secara maksimal karena kegiatan pembelajaran dilakukan secara online. Oleh karena itu, berdasarkan permasalahan tersebut pengembangan sebuah instrumen penilaian psikomotor berbasis proyek yang dapat digunakan dalam pembelajaran blended learning sangat dibutuhkan oleh guru sebagai salah satu alternatif untuk mengukur kompetensi peserta didik. Dengan adanya instrumen penilaian psikomotor berbasis proyek ini diharapkan dapat membantu guru dalam melakukan penilaian aspek psikomotor baik secara online atau offline (blended learning). Selain itu, diharapkan dapat membantu peserta didik dalam memahami materi yang disampaikan oleh guru.

\section{Ucapan Terima Kasih (Opsional)}

Peneliti mengucapkan terima kasih kepada Universitas Negeri Malang yang telah memfasilitasi dan memungkinkan peneliti dalam melakukan penelitian dan pengembangan ini.

\section{Daftar Rujukan}

Ansori, A. Z. (2017). Teknik Penilaian Proyek Dalam Pembelajaran Biologi di Madrasah Aliyah. Jurnal Diklat Keagamaan, 11 (1): 1-10

Haryati, M. (2007). Model \& Teknik Penilaian pada Tingkat Satuan Pendidikan. Jakarta: Gaung Persada Press

Indonesia, P. R. (2003). Undang-Undang Republik Indonesia Nomor 20 Tahun 2003 Tentang Sistem Pendidikan Nasional. (Online). Dari jdih.kemdikbud.go.id 
Kunandar, K. (2013). Penilaian autentik (Penilaian hasil belajar peserta didik berdasarkan Kurikulum 2013). Jakarta: Rajawali Pers

Kunandar, D. (2013). Penilaian Autentik (Penilaian Hasil Belajar Peserta Didik Berdasarkan Kurikulum 2013) Suatu Pendekatan Praktis (Edisi Revisi). Jakarta: PT Rajagrafindo Persada.

Kusaeri. (2014). Acuan \& Teknik Penilaian Proses \& Hasil Belajar Dalam Kurikulum 2013. Yogyakarta: Ar-Ruzz Media

Lestari, D., dkk. (2015), Pengembangan Instrumen Penilaian Habits Of Mind pada Pembelajaran IPA Berbasis Proyek Tema Pencemaran Lingkungan Untuk Siswa SMP. Unnes Science Education Journal, 4 (1). $796-$ 806. (Online), http://journal.unnes.ac.id/sju/index.php/usej

Majid, A. (2014). Penilaian Autentik Proses dan Hasil Belajar. Bandung: PT. Remaja Rosdakarya

Mayasari, D. (2020). Program Perencanaan Pembelajaran Matematika. Yogyakarta: CV. Budi Utama.

Pasaribu, A. \& Saparini. (2016). Pengembangan Instrumen Autentik Asesmen Berupa Penilaian Proyek dengan Produk Mind Mapping pada Materi Gaya dan Hukum Newton tentang Gerak. Jurnal Inovasi dan Pembelajaran Fisika, 1-6.

Pamungkasi, W.O., dkk. (2017). Pengembangan Instrumen Penilaian Proyek Berpendekatan Visual, Auditori, dan Kinestetik Dengan Produk Storyboard. Chemistry in Education, 6 (1). 60-66.

Pendidikan, K. (2018). Peraturan Menteri Pendidikan Nasional Republik Indonesia Nomor 34 Tahun 2018 Tentang Standar Nasional Pendidikan Sekolah Menengah Kejuruan/Madrasah Aliyah Kejuruan. Jakarta: Kementerian Pendidikan dan Kebudayaan Republik Indonesia. (Online). Dari jdih.kemdikbud.go.id

Pramana, K.A.B. \& Putra, D.B.K.N.S. (2019). Merancang Penilaian Autentik. Bali: CV Media Educations

Rahayu,W.P., dkk. (2020). Development of a Project-Based Learning Assessment System to Improve Students' Competence. Jurnal Pendidikan Ekonomi \& Bisnis, 8 (2). 86-101

Sani, R.A. (2016). Penilaian Autentik. Jakarta: PT. Bumi Aksara

Sukmasari, V.P. \& Rosana, D. (2017). Pengembangan Penilaian Proyek Pembelajaran IPA Berbasis Discovery Learning untuk Mengukur Keterampilan Pemecahan Masalah. Jurnal Inovasi Pendidikan IPA, 3 (1): 101110.

Saputra, E. H., dkk. (2018). Developing Performance-based Authentic Assessment Instruments in Learning Productive Marketing of Merchandise Planning Subject (A Study in the XI Marketing Class in SMKN 1 Turen Kabupaten Malang). The First International Research Conference on Economics and Business, KnE Social Sciences: 324-332.

Suryadi, A. (2020). Evaluasi Pembelajaran Jilid II. Sukabumi: CV. Jejak

Usman. (2018). Komunikasi Pendidikan Berbasis Blended Learning dalam Membentuk Kemandirian Belajar. Jurnalisa, 4 (1): 136-150.

Watson, J. (2008). Blended Learning: The Convergence of Online and Face-to-Face Education. Promising Practices in Online Learning. North American Council for Online Learning.

Wijayanti, A. (2014). Pengembangan Autentik Asesmen Berbasis Proyek Dengan Pendekatan Saintifik Untuk Meningkatkan Keterampilan Berpikir Ilmiah Mahasiswa. Jurnal Pendidikan IPA, 3 (2), 102-108.

Wahyuni, L \& Ruhimat, M. (2018). Pengembangan Model Penilaian Projek untuk Mengukur Aspek Psikomotor pada Mata Pelajaran Geografi. Jurnal Pendidikan Ilmu Sosial, 27 (1), 76-86.

Wardani, dkk. (2018). Daya Tarik Pembelajaran di Era 21 dengan Blended Learning. JKTP, 1 (1), 13-18

Widiara, I.K. (2018). Blended Learning Sebagai Alternatif Pembelajaran di Era Digital. Purwadiata, 2 (2), 50-56 